\title{
Growth of closed green crop surfaces in The Netherlands
}

\section{Sibma}

Institute for Biological and Chemical Research on Field Crops and Herbage (I.B.S.), Wageningen, The Netherlands

Received 1 June, 1968

\section{Summary}

A number of experiments with different crops grown under optimal and near optimal soil conditions are described. Crop growth rates were calculated for that period of each crop during which a completely closed green crop surface could be assumed to be present.

For a range of crop plants it is shown that during the summer period, crop growth rates vary between 162 and $228 \mathrm{~kg} \mathrm{ha}^{-1}$ day-1. Differences in growth rate can be attributed to differences in the percentage of the total plant weight harvested.

When growth rates for total dry matter are estimated it is concluded that differences in growth rates between crops are small.

\section{Introduction}

Wassink (1948) calculated the average efficiency of light conversion of some crops throughout their growing period. Gaastra (1958) demonstrated that the values of $1.5 \%$ thus obtained were the result of the crop not showing a completely closed leaf canopy during a considerable part of the growing period. The efficiency of sugar beets in the period before a closed leaf canopy develops is $0.3 \%$ but after this it is nearer 5\%. After De Wit (1959) developed a method to calculate the potential production of a closed green crop surface attempts were made to bring the actual production rates of a closed leaf canopy under optimum soil conditions to the level of the potential rates.

In addition to agricultural crops the production of algal cultures has been investigated. By developing and applying correct cultivation techniques, it was hoped that if high light efficiency could be demonstrated, the large-scale cultivation of this protein rich material might be feasible in certain situations in the world.

In this paper the growth rates of a number of crops are compared. The data, drawn mainly from Dutch research, are taken from experiments in which growing conditions are assumed to have been near optimal.

In comparing growth rates of different crops two problems arise. In the first place, it is difficult to establish from published data, during what part of the growth period the green leaf canopy of the crop was closed. In the second place, not all the dry matter produced is always harvested. The underground part of the beet and the potato plant not harvested is small. That part of peas and maize remaining in the field is relatively small, because almost the whole stem is harvested. An appreciably greater part of annual cereals is left in the field as stubble and root, and a considerably 
greater part still of perennial grasses, since the root system of these remains alive. Calculations of growth rates based only on the dry matter harvested, makes comparisons tenuous.

Concerning the first point Alberda (1968) demonstrated that the production of grass was linear after a dry weight of $1500 \mathrm{~kg} \mathrm{ha}^{-1}$ had been attained. For other crops it was assumed that the crop had attained a closed green leaf canopy when a dry weight was harvested of $1500 \mathrm{~kg} \mathrm{ha}^{-1}$. The end of this period was assumed to be at the moment the growth rate started to decrease.

Below a number of experiments are described, in which the objective was the highest possible dry matter production through the supply of water and minerals to the crop at optimum rates; or which were afterwards proved to have had a high production rate. The crops examined are listed in Table 1; only the highest growth rate observed for each crop is given in the table.

\section{Crops}

\section{Grass}

Experiments of Alberda and Sibma (1968) showed that with optimum water and mineral supply the dry matter production of grass varied only slightly between soil types and from year to year. A typical growth curve for perennial ryegrass is shown as curve number 1 in Figure 1.

\section{Wheat}

In an experiment with winter wheat varieties on clay soil in the Northeast Polder in 1965 , De Vos (pers. comm.) established that the variety Cleo produced the earliest and highest dry matter yields. The yields of this variety are shown in Fig. 1. The growth rate before 3 May was low due to insufficient soil coverage; after 12 july the crop became diseased.

Mixed cultures, oats + barley and oats + peas

In these two mixtures the crops were sown in alternate rows $25 \mathrm{~cm}$ apart, a plant density corresponding to normal seed rates of a monoculture of each crop. The results given in Fig. 1 were obtained on a moisture retaining sandy soil near Wageningen. The greatest possible portion of the above-ground parts was harvested.

Oats

1964 yield data for the variety Marne sown at $115 \mathrm{~kg} \mathrm{ha}^{-1}$ on good, moisture retaining sandy soil have been selected.

Peas

This crop is represented by 1964 growth data of the variety Pauli sown at a rate of $224 \mathrm{~kg} \mathrm{ha}-1$. A mixture of tall (Mechelse Krombek) and short straw blue peas (Pauli) did not show a higher production in 1966 than the monocultures of these varieties.

\section{Spring barley}

In $1966,132 \mathrm{~kg} \mathrm{ha}^{-1}$ of the variety Impala was sown on clay soil in East Flevoland. The growth curve from 7 June to 19 July, given in Fig. 1, corresponds with 


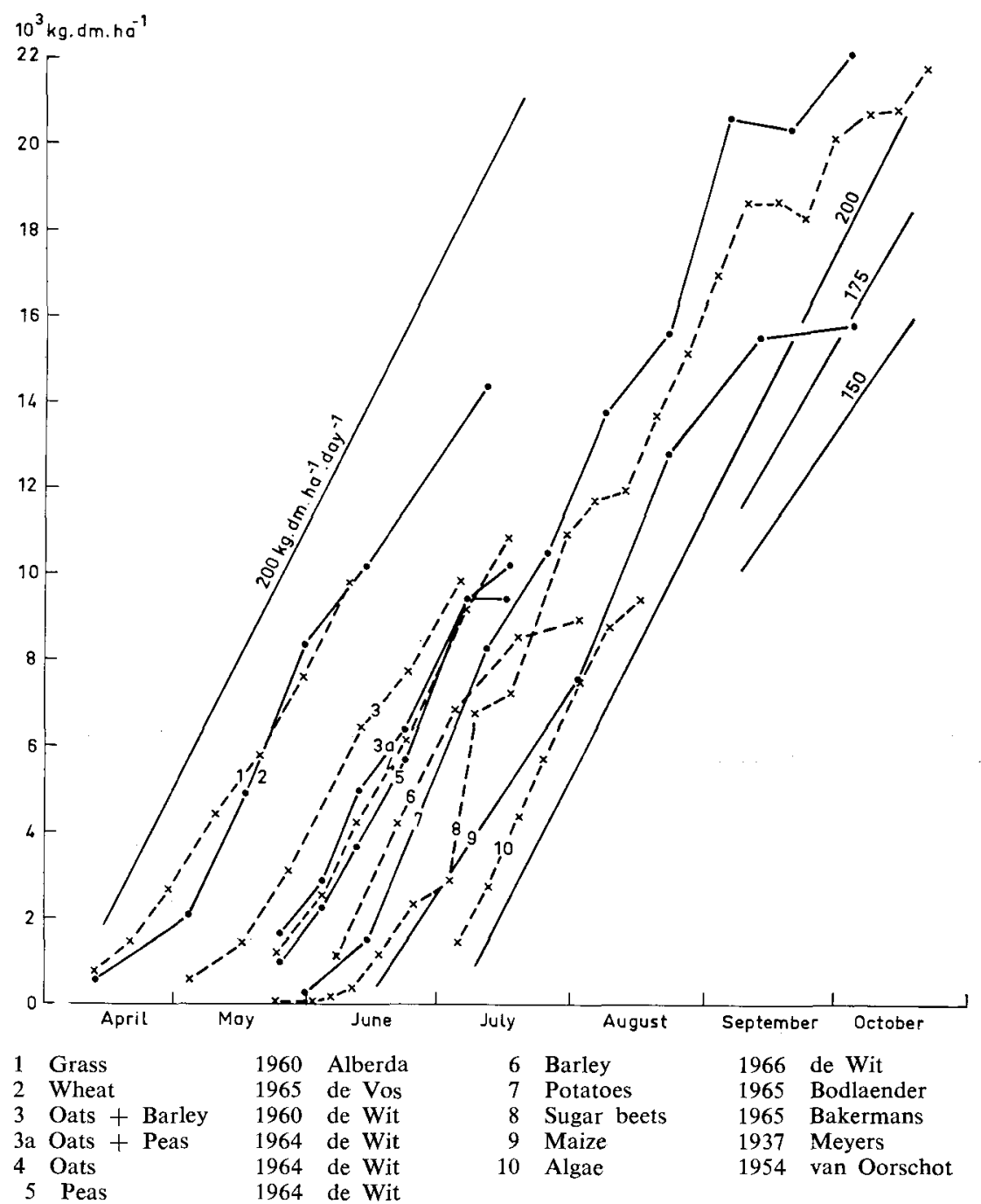

Fig. 1 Comparison of growth rates of agricultural crops and algae with the curves corresponding to 200,175 and $150 \mathrm{~kg} \mathrm{ha-1} \mathrm{day-1}$

the dry matter production of spring barley as established by Van Roon (1959) on sandy clay soil. The production of the variety Herta on sandy soil in other years was appreciably lower.

\section{Potatoes}

In 1965 Bodlaender (1966) obtained growth curves for potatoes grown under irrigation at different nitrogen levels and with treatments including application of the growth retardant B 995. 

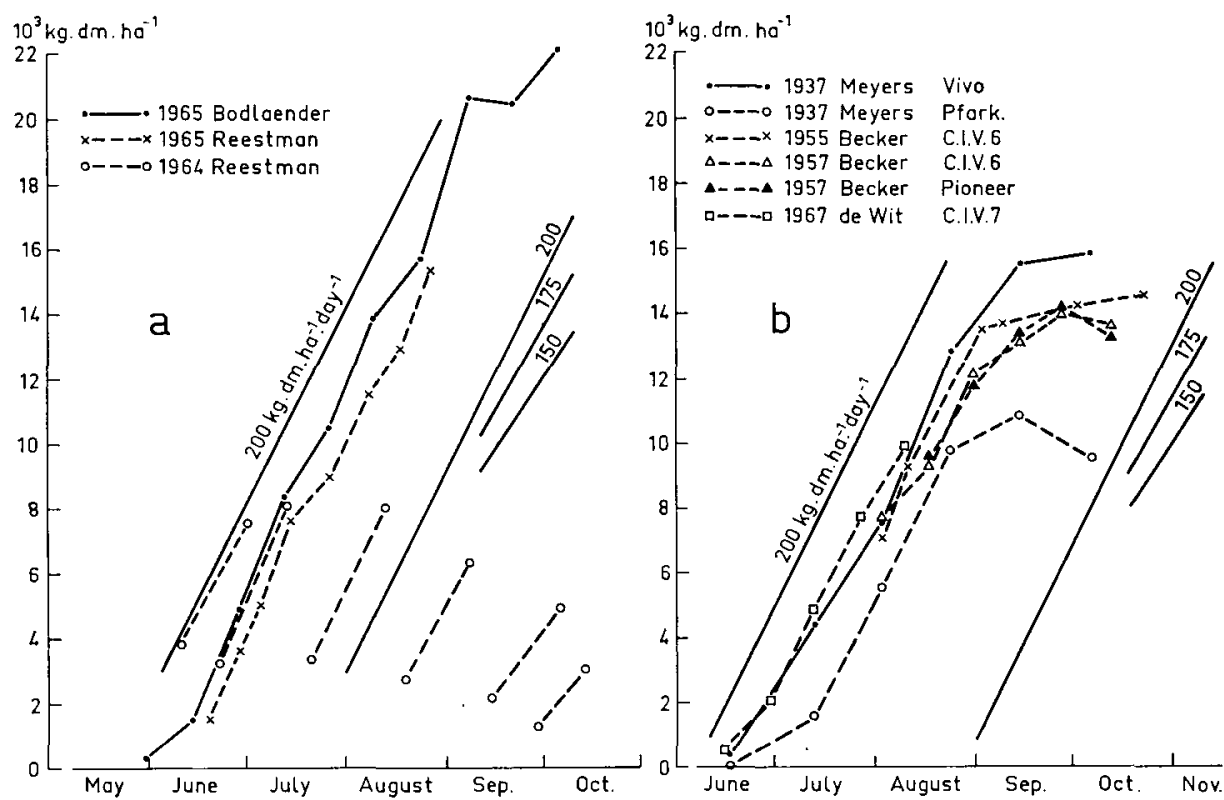

Fig. 2 Growth rates of potatoes according to Bodlaender and Reestman (a) and of maize varieties according to Meyers, Becker and de Wit (b)

Fig. 2a compares the curve obtained by Bodlaender with B 995 and $200 \mathrm{~kg} \mathrm{~N}$ ha-1 with others recorded by Reestman (unpub.) using the variety Spartaan. The yields of a planting and harvest interval experiment on good, sandy soil, also with sprinkling, in 1964, showed growth curves of the same order during the months June, July and August.

Beets

The growth curve of this crop given as curve number 8 in Fig. 1 was obtained by Bakermans (pers. comm.) with the variety Hilleshög Polyploid on river clay soil in 1965. The slope of the curve corresponds to that of the most productive variety in a variety experiment of Boonstra (1939) on river clay soil. In time Bakermans' curve is about 20 days earlier and therefore the final yield is greater.

Maize

The varieties Pfarkirchener (grain maize) and Vivo (silage maize), periodically harvested by Meyers (1939), were sown on good, moisture retaining sandy soil, dressed with farmyard manure. Plant density was 16 to 17 plants $\mathrm{m}^{-2}$. For comparison, the dry matter yields of the variety C.I.V. 6 at a plant density of 25 plants $\mathrm{m}^{-2}$ (De Wit (unpublished) and some experiments by Becker $(1955,1957)$ ) have been given in Fig. $2 b$.

Algae

Van Oorschot (1955) and Kok (1954) tried to obtain the highest possible production with algae cultures on culture solutions. The productions established by Van 
GROWTH OF CLOSED GREEN CROP SURFACES IN THE NETHERLANDS

Table 1 Growth rate and number of days during which a closed canopy occurred for different agricultural crops

\begin{tabular}{|c|c|c|c|c|c|c|}
\hline Crops & $\begin{array}{l}\text { Date of } \\
\text { canopy } \\
\text { closure }\end{array}$ & $\begin{array}{l}\text { Date of } \\
\text { growth rate } \\
\text { reduction }\end{array}$ & $\begin{array}{c}\text { Number of } \\
\text { days }\end{array}$ & $\begin{array}{c}\text { Difference } \\
\text { in } \mathrm{kg} \mathrm{d.m.} \\
\mathrm{ha}-1\end{array}$ & $\begin{array}{c}K g \text { d.m. } \\
h a-1 \text { day-1 }\end{array}$ & Group \\
\hline Potatoes & $14 / 6$ & $6 / 9$ & 84 & 19.150 & 228 & \\
\hline Beets & $17 / 6$ & $10 / 9$ & 85 & 17.500 & 206 & Root crops \\
\hline Peas & $25 / 5$ & $7 / 7$ & 43 & 8.450 & 196 & Peas \\
\hline Algae & $5 / 7$ & $16 / 8$ & 42 & 8.000 & 191 & Algae \\
\hline Oats + peas & $25 / 5$ & $17 / 7$ & 53 & 9.700 & 183 & Mixed culture \\
\hline Spring barley & $7 / 6$ & $19 / 7$ & 42 & 7.450 & 177 & \\
\hline Winter wheat & $3 / 5$ & $12 / 7$ & 69 & 12.300 & 175 & \\
\hline Maize & $16 / 6$ & $13 / 9$ & 88 & 15.050 & 171 & Cereals \\
\hline Oats & $24 / 5$ & $16 / 7$ & 53 & 8.950 & 169 & \\
\hline Oats + barley & $16 / 5$ & $6 / 7$ & 51 & 8.500 & 167 & \\
\hline Grass & $20 / 4$ & $10 / 6$ & 51 & 8.250 & 162 & Grass \\
\hline
\end{tabular}

Oorschot are represented in a comparative way to agricultural crops in Table 1 and Fig. 1.

\section{Discussion}

In Table 1 the crops have been arranged according to a decreasing average growth rate. This arrangement corresponds with a decrease in the percentage of the total plant weight that was harvested.

A greater part of the total yield of root crops is harvested than of spring cereals. Despite the optimum supply of water and minerals, grass is conspicuous by the lowest above-ground production. According to Alberda (1962) the above-ground production is $60 \%$ or less of the total yield. To find the total yield, the above-ground production should be multiplied by 1.67 . If this is done the daily production of grass is equivalent to that of potatoes. Under frequent cutting the daily growth rate of grass is reduced, because after cutting growth is always interrupted. Despite a much longer growing period, grass does not yield more dry matter proportionally. Maize was not found to have a higher production rate than other crops despite the demonstration by Hesketh and Moss (1963) that is has a higher assimilation rate per unit of leaf area. If root growth is put at $20 \%$, the total production of maize

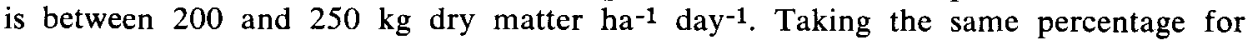
root growth in cereals, a similar production is attained by these crops, which consequently is equivalent to that of the root crops.

The growth rate of algae may be seen to be similar to that of many agricultural crops. Especially, because the total yield of grass and cereals is actually higher, because of the production of the non-harvested root parts. However, since the growth of algae is not interrupted, as in grass, the annual production will undoubtedly be higher.

Table 1 also shows that the number of days after $1500 \mathrm{~kg}$ of dry matter ha-1 has been produced and before a decrease in growth rate occurs, is greatest in root crops and is generally smallest in spring cereals. Winter wheat and maize are intermediate for the number of growing days. Peas correspond to spring cereals. 
At the time maize starts growth, grass and winter wheat have already produced 10 tons dry matter ha-1. Hence, in growing maize, part of the radiation energy in spring is lost. In winter wheat a similar situation occurs during late summer. Although potatoes and beets when compared with grass and wheat are late in forming a closed green leaf canopy, the growing period is long, consequently the annual production is high.

It is concluded that many agricultural crops in the Netherlands have a main growth rate of about $250 \mathrm{~kg}$ dry matter ha-1 day $^{-1}$ from the time the soil is covered completely by a closed green crop surface to near maturity. Differences in total dry matter production between crops are determined more by the duration of the growing period than by the differences in growth rate. With optimum supply of water and minerals the growth rate appears to be determined by climatological factors rather than by those associated with the crop and soil.

\section{Literature}

Alberda, Th., 1962. Actual and potential production of agricultural crops. Neth. J. agric. Sci., 10 : $325-333$.

Alberda, Th. and L. Sibma, 1968. Dry matter production and light interception. III. Actual herbage production in different years as compared with potential values. J. Brit. Grassland Soc. (in press).

Bakermans, W. A. P. : unpublished.

Becker, W. R. and G. H. de Haan, 1956. Een proef met verschillende oogsttijden van snijmais. Verslag C.I.L.O. 1955 : 170-176.

Becker, W. R., 1958. The influence of variety, stage of maturity and cultural practices on yield and quality of maize for silage. Tenth F.A.O. Hybrid maize meeting, Madrid.

Bodlaender, K. B. A. and S. Algra, 1966. Influence of the growth retardant B 995 on growth and yield of potatoes. Europ. Potato J., $9: 242-258$.

Gaastra, P., 1958. Light energy conversion in field crops in comparison with fotosynthetic efficiency under laboratory conditions. Meded. Landbouwhogeschool, Wageningen, Nederland, 58 (4) : 1-12.

Hesketh, J. D. and D. N. Moss, 1963. Variation in the response of photosynthesis to light. Crop Sci. : $107-110$.

Kok, B. and J. L. P. van Oorschot, 1954. Improved yields in algal cultures. Acta Bot. Neerl. 3 : 533-546.

Meijers, P. G., Th. B. van Itallie and J. J. Manschot, 1939. De productiegang van mais. Versl. landbouwk. Onderz. 45 (4) A : 71-117.

Oorschot, J. L. P. van, 1955. Conversion of light energy in algal culture. (Thesis). Meded. Landbouwhogeschool, Wageningen, Nederland, 55 (5) : 225-276.

Reestman, A. : unpublished.

Roon, E. van, 1959. De toepassing van gedeelde $\mathrm{N}$-giften bij enkele zaadteeltgewassen. (Thesis). Publ. Proefst. Akker- en Weidebouw, Wageningen, Nederland, 6: 1-131.

Vos, N. M. de : Unpublished.

Wassink, E. C., 1948. De lichtfactor in de photosynthese en zijn relatie tot andere milieufactoren. Meded. Dir. Tuinb. 11 : 503-511.

Wit, C. T. de, 1959. Potential photosynthesis of crop surfaces. Neth. J. agric. Sci., $7:$ 141-149. 